\title{
PEMANFAATAN PISANG KEPOK (MUSAPARADISIACA FORMATYPICA) DAN TERUNG BELANDA (SOLANUM BETACEUM CAV.) PADA PEMBUATAN FRUIT LEATHER
}

\author{
(Utilization of Kepok Banana (Musa Paradisiaca Formatypica) and Belanda (Solanum \\ Betaceum Cav.) in Fruit Leather Making)
}

\author{
Mulyati M. Tahir ${ }^{1 *}$, Abu Bakar Tawali ${ }^{1)}$, dan Ferty Desy Andriana ${ }^{1)}$ \\ ${ }^{1 *}$ Program Studi Ilmu dan Teknologi Pangan Departemen Teknologi Pertanian Universitas Hasanuddin \\ Makassar, Indonesia \\ *)email Penulis Korespondensi: p.mulyati@yahoo.com
}

\begin{abstract}
ABSTRAK
(Musaparadisiaca formatypica) adalah salah satu buah yang mengandung cukup banyak serat pencernaan bagi tubuh. Pisang kepok (Musaparadisiaca formatypica) biasanya diolah dengan cara digoreng atau dikukus, pisang memiliki umur simpan yang pendek dan mudah rusak. Karena itu, untuk memperpanjang umur simpan pisang, buah akan diolah menjadi produk kulit buah. Namun, karena warna pisang kurang menarik, penambahan warna akan membuat produk disukai oleh konsumen. Terung belanda (Solanum betaceum cav. Memiliki warna yang cerah dan memiliki kandungan serat yang cukup diolah menjadi kulit buah. Tujuan penelitian ini adalah untuk menemukan kombinasi perlakuan terbaik antara pisang kepok (Musaparadisiaca formatypica) dan terung belanda (Solanum betaceum cav. ) konsentrasi gula untuk menghasilkan sifat fisik dan kimia yang baik dan disukai konsumen.Penelitian ini juga untuk mengetahui pengaruh penambahan kadar gula terhadap pisang kulit buah, kulit dan kimia serta terung belanda (Solanum betaceum cav.). adalah A1: pisang kepok (Musaparadisiaca formatypica) dihaluskan 50\%: terung belanda (Solanum betaceum cav) tumbuk 45\%: gula 5\%; A2: 45\%: 40\%: 15\%; A3: 40\%: 35\%: 25\% Kulit buah kemudian diuji secara organoleptik termasuk warna, rasa, rasa dan tekstur dan diuji secara kimia termasuk kadar air, total asam, $\mathrm{pH}$, antosianin dan serat.Hasil penelitian menunjukkan bahwa perlakuan A1: $50 \%$ pisang kepok : terung belanda bubur 45\%: 5\% gula menghasilkan produk kulit buah terbaik dari segi kadar air, asam total, $\mathrm{pH}$, antosianin, serat, aroma, rasa, dan tekstur.
\end{abstract}

Kata Kunci : kepok pisang (Musaparadisiaca formatypica), terung belanda (Solanum betaceum cav.), kulit buah

\section{ABSTRACT}

Kepok banana (Musaparadisiaca formatypica) is one fruit that contains enough digestive fiber for the body. Kepok banana (Musaparadisiaca formatypica) is usually processed by frying or steaming, bananas have a short shelf life and easily damaged. Therefore, to extend the shelf life of bananas, fruit will be processed into fruit leather products. However, because the color of bananas are less attractive, the color addition will make the product preferred by consumers. Terung belanda (Solanum betaceum cav. has a bright color and has enough fiber content so well processed into fruit leather. The objective of this research was to find the best treatment combination between kepok banana (Musaparadisiaca formatypica) and terung belanda (Solanum betaceum cav.) sugar concentration to produce a good physical and chemical properties and favored by consumers. The research was also to find out the effect of sugar concentration addition to physical, chemical and organoleptic fruit leather banana and terung belanda (Solanum betaceum cav.). Treatment applied was A1: kepok banana (Musaparadisiaca formatypica) mashed 50\%: 
terung belanda ((Solanum betaceum cav) mashed 45\%: sugar 5\%; A2: 45\%: 40\%: 15\%; A3: 40\%: 35\%: 25\%. Fruit leather is then tested organoleptically including color, flavor, taste and texture and was chemically tested including moisture content, total acid, pH, anthocyanin and fiber. The result of the research shows that Al treatment: $50 \%$ banana porridge: terung belanda porridge 45\%: 5\% sugar produces the best fruit leather product in terms of water content, total acid, $\mathrm{pH}$, anthocyanin, fiber, aroma, taste, and texture.

Keywords : kepok banana (Musaparadisiaca formatypica), terung belanda (Solanum betaceum cav.), fruit leather

\section{PENDAHULUAN}

Buah-buahan merupakan salah satu jenis komoditi hasil pertanian yang mengandung vitamin dan mineral yang cukup tinggi sehingga sangat bermanfaat bagi tubuh. Namun, buah-buahan mudah mengalami kerusakan fisik maupun mekanik jika tidak dilakukan penyimpanan pada suhu yang sesuai. Pada dasarnya masyarakat mengkonsumsi buah-buahan secara langsung atau dengan mengolah buah tersebut menjadi juice. Namun seiring berkembangnya teknologi, berbagai macam buah-buahan telah dilakukan penganekaragaman guna memperpanjang umur simpan dari buah tersebut dan menghasilkan produk-produk baru dan inovatif. Salah satu bentuk penganekaragaman buah yaitu dengan mengolah buah menjadi fruit leather.

Fruit leather merupakan produk pangan semi basah yang berbentuk lembaran tipis dan memiliki plastisitas yang baik sehingga mudah digulung. Fruit leather terbuat dari buah-buahan atau sayuran yang mengandung serat cukup tinggi melalui pengeringan dengan diberi bahan tambahan. Terdapat beberapa buah yang mengandung serat yang cukup tinggi dengan kisaran 0,5 - 4,29 g dalam $100 \mathrm{~g}$ bahan yaitu pisang kepok dan terung belanda.

Pisang kepok merupakan salah satu buah yang mengandung serat cukup tinggi sehingga mampu melancarkan system perncernaan didalam tubuh. Pisang kepok merupakan pisang yang biasa dikonsumsi setelah dilakukan pengolahan terlebih dahulu seperti digoreng atau dikukus.
Menurut (Rohimah, 2016) berdasarkan Badan Pusat Statistik selama 2011-2015 rata-rata pertumbuhan produksi pisang di Indonesia sebesar 4,92\%. Pada tahun 2015 total produksi pisang di Indonesia naik secara signifikan mencapai 7,3 juta ton. Sehingga dengan melimpahnya buah pisang ini dapat dimanfaatkan sebagai produk olahan pangan. Namun, pisang memiliki umur simpan yang cukup singkat sehingga perlu dilakukan pengolahan untuk memperpanjang masa simpannya. Warna pisang yang kurang menarik akan membuat produk kurang disukai sehingga perlu dikombinasikan dengan terung belanda.

Terung belanda merupakan salah satu buah yang mengandung senyawa beta karoten, antosianin dan serat. Beta karoten merupakan salah satu jenis karotenoid yang banyak terdapat pada buah-buahan. Selain beta karoten, terung belanda juga memiliki pigmen warna merah yang tergolong dalam kelompok flavonoid. Pigmen warna merah dalam terung belanda disebut antosianin yang bersifat sebagai antioksidan sehingga dapat menangkal radikal bebas dalam tubuh. Berdasarkan data (Badan Pusat Statisti, 2013).

Produksi terung belanda di Indonesia pada tahun 2010 adalah 482.305 ton, tahun 2011 adalah 519.481 ton dan tahun 2012 adalah 518.448 ton. Pigmen warna yang terkandung dalam buah terung belanda ini diharapkan mampu membuat warna dari fruit leather semakin disukai. Selain itu, kandungan serat yang cukup tinggi pada buah ini dapat berfungsi untuk melancarkan pencernaan dalam tubuh. Berdasarkan latar belakang tersebut, maka penelitian ini dilakukan untuk mengkombinasikan buah 
pisang kepok dan terung belanda yang diketahui memiliki kandungan gizi yang tinggi dan memiliki beberapa zat yang penting untuk kesehatan. Penambahan terung belanda juga merupakan salah satu cara untuk mendapatkan warna fruit leather yang menarik sehingga dapat disukai oleh masyarakat.

merupakan salah satu buah yang sering dijumpai di pasar tradisional. Keberadaannya yang melimpah membuat buah ini dapat dimanfaatkan menjadi berbagai macam produk olahan. Umur simpannya yang tidak panjang membuat buah ini cepat mengalami kerusakan. Kurangnya pengetahuan masyarakat untuk mengolah pisang membuat buah ini biasanya hanya dikonsumsi secara langsung atau dengan cara dikukus dan digoreng. Kandungan serat yang dimiliki oleh buah ini sangat berfungsi bagi tubuh untuk melancarkan system pencernaan. Selain pisang, terdapat buah yang memiliki kandungan serat yang tinggi yaitu terdapat pada terung belanda. Buah ini kurang dimanfaatkan oleh masyarakat. Biasanya beberapa masyarakat hanya mengolah buah ini dalam bentuk juice. Rasanya yang masam membuat buah ini kurang disukai oleh masyarakat namun warna dari buah ini sangat menarik yaitu berwarna merah. Buah ini sering dijumpai di pasar tradisional bahkan supermarket. Salah satu pengolahan yang tepat untuk kedua buah ini yaitu mengolahnya menjadi fruit leather. Fruit leather ini diharapkan dapat menjadi cemilan sehat yang dapat membantu tubuh untuk melancarkan pencernaan. Selain mengandung serat, fruit leather ini akan mengandung beberapa vitamin yang sangat baik untuk tubuh.

Tujuan yang ingin dicapai dari penelitian ini adalah untuk mengetahui kombinasi perlakuan terbaik antara konsentrasi pisang dan terung belanda serta gula terhadap fruit leather yang dihasilkan dengan sifat fisik dan kimia yang baik serta disukai oleh konsumen dan untuk mengetahui pengaruh penambahan konsentrasi gula terhadap sifat fisik, kimia dan organoleptik fruit leather pisang dan terung belanda.

Kegunaan dari penelitian ini yaitu untuk meningkatkan pemanfaatan buah pisang dan terung belanda agar dapat memperpanjang masa simpan buah tersebut, meningkatkan nilai ekonomis buah pisang dan terung belanda, serta untuk menghasilkan penganekaragaman produk fruit leather dengan kualitas yang baik.

\section{METODOLOGI PENELITIAN}

\subsection{Alat}

Alat-alat yang digunakan pada penelitian ini adalah timbangan analitik, blender, hotplate, gelas kimia, batang pengaduk, loyang, blower, sendok, pisau, saringan, wadah, sendok, spatula karet, thermometer, erlenmeyer, $\mathrm{pH}$ meter, pipet tetes, cawan, oven, desikator.

\subsection{Bahan}

Bahan yang digunakan pada penelitian ini adalah pisang kepok, terung belanda, gula, jeruk nipis, gum arab, aluminium foil, tissue, $\mathrm{NaOH} 0,1 \mathrm{~N}$, indikator phenolptalin (pp), aquades, larutan buffer fosfat $\mathrm{pH} 7$, buret.

\subsection{Prosedur Penelitian}

\subsubsection{Pembuatan bubur buah pisang}

Prosedur kerja yang dilakukan pada penelitian ini adalah sebagai berikut:

1. Pencucian

Pisang dicuci terlebih dahulu dengan menggunakan air bersih untuk menghilangkan kotoran yang menempel pada pisang

2. Pengukusan

Pisang yang telah dicuci kemudian dikukus selama 10 menit. Tujuan pengukusan ini untuk menonaktifkan enzim terutama enzim pencoklatan dan mikroorganisme patogen yang tidak baik bagi kesehatan

3. Pengupasan

Pisang yang telah dikukus kemudian dikupas kulitnya. 
4. Pemotongan

Pisang yang telah dikupas kulitnya, diambil daging buahnya dan dipotongpotong. Tujuan pemotongan ini yaitu untuk mempermudah selama proses penghalusan

5. Penghalusan

Pisang yang telah dipotong kemudian dihaluskan dengan menggunakan blender halus menjadi bubur buah pisang.

\subsubsection{Pembuatan bubur buah terung belanda}

Prosedur kerja yang dilakukan pada penelitian ini adalah sebagai berikut:

1. Pencucian

Terung belanda dicuci terlebih dahulu dengan menggunakan air bersih untuk menghilangkan kotoran yang menempel pada permukaan buah.

2. Pemotongan dan pengambilan daging buah

Terung belanda yang telah dicuci kemudian dipotong menjadi dua bagian kemudian diambil daging buahnya

3. Penyaringan

Daging buah terung belanda tersebut kemudian disaring untuk memisahkan daging buah dari bijinya.

4. Penghalusan

Terung belanda yang telah disaring kemudian dihaluskan dengan menggunakan blender hingga halus menjadi bubur buah.

\subsubsection{Pembuatan Fruit Leather Pisang dan Terung belanda}

Prosedur kerja yang dilakukan pada penelitian ini adalah sebagai berikut:

1. Pencampuran

Bubur buah pisang dan bubur buah terung belanda dicampurkan dan ditambahkan bahan tambahan seperti gula, jeruk nipis dan gum arab.

2. Pemanasan

Bahan yang telah dicampurkan kemudian dilakukan pemanasan dengan suhu $70-80^{\circ} \mathrm{C}$ selama 2 menit

3. Pencetakan
Setelah dipanaskan, adonan tersebut dicetak pada loyang yang telah dilapisi aluminium foil dan diratakan menggunakan spatula karet hingga ketebalannya 2-3 mm.

4. Pengeringan

Adonan yang telah dicetak kemudian dikeringkan menggunakan blower dengan suhu $60^{\circ} \mathrm{C}$ selama 24 jam.

5. Pemotongan

Fruit leather yang telah dikeringkan kemudian dipotong-potong dengan ukuran $2 \times 3 \mathrm{~cm}$

\subsection{Perlakuan Penelitian}

\subsubsection{Penelitian Pendahuluan}

Penelitian pendahuluan ini dilakukan untuk mendapatkan perbandingan jumlah buah yang tepat pada pembuatan fruit leather, dengan perlakuan sebagai berikut:

A1 : bubur buah pisang $60 \%$ : bubur buah terung belanda $15 \%$ : gula $25 \%$

A2 : bubur buah pisang 50\% : bubur buah terung belanda $25 \%$ : gula $25 \%$

A3 : bubur buah pisang $40 \%$ : bubur buah terung belanda $35 \%$ : gula $25 \%$

\subsubsection{Penelitian Utama}

Hasil terbaik dari penelitian pendahuluan yaitu perlakuan A3 : $40 \%$ pisang $+30 \%$ terung belanda diberi perlakuan konsentrasi gula masing-masing $20 \%$, 30\% dan 40\%. Setelah itu, produk dikeringkan dan dilakukan pengujian organoleptik dengan metode hedonic serta dilakukan uji kimia meliputi total asam, $\mathrm{pH}$, kadar air, kadar serat dan uji antosianin. Perlakuan yang diterapkan adalah sebagai berikut:

A1 : bubur buah pisang 50\% : bubur buah terung belanda $45 \%$ : gula $5 \%$

A2 : bubur buah pisang $45 \%$ : bubur buah terung belanda $40 \%$ : gula $15 \%$

A3 : bubur buah pisang $40 \%$ : bubur buah terung belanda $35 \%$ : gula $25 \%$

\subsubsection{Parameter pengamatan}


Parameter pengamatan pengujian fruit leather yaitu Uji Organoleptik (hedonic) (Rampengan, 1985), Kadar Air (AOAC, 1990), Total Asam (Sudarmadji, Haryono, \& Suhardi, 1997), pengukuran $\mathrm{pH}$ Kadar Serat dan Antosianin (Giusti \& Wrolstad, 2001).

\subsection{Pengolahan Data}

Data yang diperoleh pada analisa kimia diolah dengan analisis sidik ragam menggunakan Rancangan Acak Lengkap (RAL) dengan 3 kali ulangan, jika perlakuan berpengaruh nyata terhadap parameter maka dilanjutan dengan menggunakan uji lanjut Duncan. Sedangkan untuk data hasil uji organoleptik diolah secara deskriptif kuantitatif.

\section{HASIL DAN PEMBAHASAN}

\subsection{Penelitian Pendahuluan}

Berdasarkan hasil penelitian pendahuluan menunjukkan bahwa dari ketiga perlakuan perbandingan konsentrasi bubur buah, skor tertinggi dari tingkat kesukaan panelis yaitu terdapat pada perlakuan A3 : bubur buah pisang 40\% : bubur buah terung belanda $35 \%$ : gula $25 \%$ dengan nilai warna 3.8 , aroma 2.8 , rasa 3.8 dan tekstur 3.6. Sedangkan skor terendah yaitu terdapat pada perlakuan A1 : bubur buah pisang $60 \%$ : bubur buah terung belanda $15 \%$ : gula $25 \%$ dengan nilai warna 2.3, aroma 2.5, rasa 3.6, dan tekstur 2.7. Hasil dari pengujian organoleptic pada penelitian pendahuluan dapat dilihat pada gambar 1

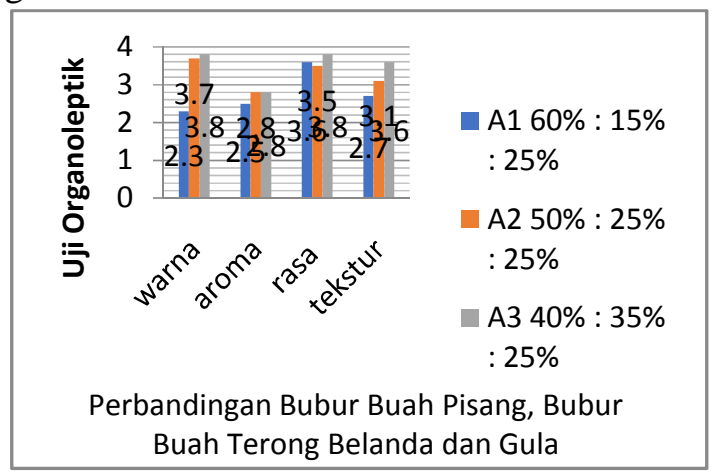

Gambar 1 Hasil Organoleptik Penelitian Pendahuluan
Berdasarkan gambar 1 diatas menunjukkan bahwa formulasi konsentrasi terbaik yang disukai oleh panelis berdasarkan pengujian organoleptic parameter warna, rasa, aroma dan tekstur terdapat pada perlakuan A3 : bubur buah pisang $40 \%$ : bubur buah terung belanda $30 \%$ : gula $25 \%$. Oleh karena itu, perlakuan tersebut akan dilanjutkan pada penelitian utama untuk mengetahui pengaruh penambahan konsentrasi gula yang berbeda-beda.

\subsection{Penelitian Utama}

Penelitian utama dilakukan untuk mengetahui pengaruh penambahan konsentrasi gula yang berbeda-beda. Pada penelitian ini formulasi bubur buah dari penelitian pendahuluan berdasarkan hasil uji organoleptic terbaik baik dari segi warna, aroma, rasa dan tekstur yaitu terdapat pada perlakuan A3 yaitu bubur buah pisang $40 \%$ : bubur buah terung belanda 30\% : gula $25 \%$. Sehingga pada penelitian utama ini akan dilakukan penambahan konsentrasi gula dalam jumlah yang berbeda-beda untuk mengetahui pengaruh penambahan gula tersebut terhadap analisa kimia meliputi kadar air, total asam, $\mathrm{pH}$, antosianin dan serat maupun organoleptic meliputi warna, aroma, rasa dan tekstur dari produk yang dihasilkan.

\subsection{Analisa Kimia}

\subsubsection{Kadar Air}

Kandungan air dalam bahan pangan memiliki peranan yang sangat penting karena dapat menentukan acceptability, kesegaran, dan sangat berpengaruh pada masa simpan bahan pangan, karena air dapat mempengaruhi beberapa sifat fisik antara lain tekstur, kenampakan dan cita rasa makanan (Musfiroh, Indriyati, \& Muchtaridi, 2009), Kadar air produk fruit leather tertinggi diperoleh pada perlakuan A1 : bubur buah pisang $50 \%$ : bubur buah terung belanda $45 \%$ : gula $5 \%$ yaitu sebesar $10.95 \%$. Kadar air terendah diperoleh pada perlakuan A3 : bubur buah pisang 40\%: 
bubur buah terung belanda $35 \%$ : gula $25 \%$ yaitu sebesar $7.99 \%$. Kadar air pada produk fruit leather dapat dilihat pada Gambar 2.

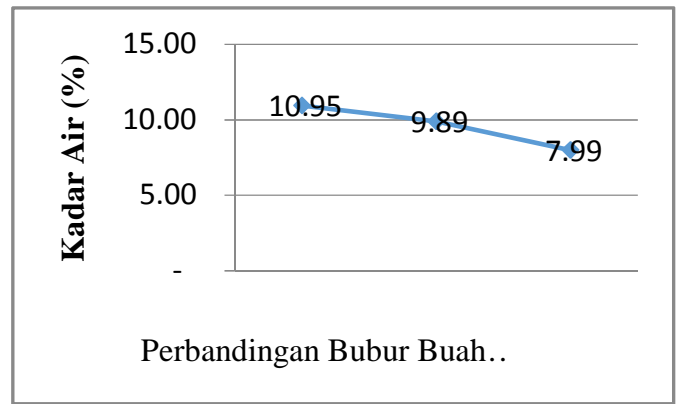

Gambar 2 Pengaruh Perbandingan Pisang Kepok, Terung Belanda dan Gula Terhadap Kadar Air Fruit Leather

Hasil analisa sidik ragam menunjukkan bahwa adanya pengaruh nyata $(\mathrm{p}<0,05)$ pada perbandingan bubur buah dan penambahan konsentrasi gula yang berbeda terhadap kadar air fruit leather yang dihasilkan sehingga dilakukan uji lanjut Duncan. Hasil uji analisa Duncan memperlihatkan bahwa kadar air yang dihasilkan berbeda nyata pada taraf $5 \%$. Hal tersebut dikarenakan penambahan gula yang tinggi akan menyebabkan gula mengikat air (higroskopis) sehingga penambahan gula menyebabkan terikatnya sebagian air dari bahan yang menyebabkan jumlah air bebas berkurang. Oleh sebab itu semakin tinggi penambahan gula maka kadar air akan semakin rendah. Hal ini sesuai dengan pernyataan (Buckle \& Edward, 1987) yang menyatakan bahwa, gula mempunyai kemampuan untuk mengikat air yang ada dalam bahan pangan. Terjadinya ikatan hidrogen yang menyebabkan berkurangnya aktivitas air dalam bahan pangan tersebut. Kadar air fruit leather yang baik yaitu $10-25 \%$, nilai Aw kurang dari 0,7, tekstur plastis, kenampakan seperti kulit, terlihat mengkilap, dapat dikonsumsi secara langsung serta mempunyai warna, aroma dan citarasa khas suatu jenis buah sebagai bahan baku.

\subsubsection{Total Asam}

Total asam merupakan ukuran dari keseluruhan asam yang terkandung dalam suatu bahan. Total asam terkait dengan $\mathrm{pH}$ namun beda prinsip. Kadar $\mathrm{pH}$ mengukur kekuaan total asam, sedangkan total asam mengukur jumlah asam (Winarno, 2004). Total asam produk fruit leather tertinggi diperoleh pada perlakuan A1 : bubur buah pisang $50 \%$ : bubur buah terung belanda $45 \%$ : gula $5 \%$ yaitu sebesar $0,27 \%$. Total asam terendah diperoleh pada perlakuan A3 : bubur buah pisang $40 \%$ : bubur buah terung belanda $35 \%$ : gula $25 \%$ yaitu sebesar $0.13 \%$. Kadar air pada produk fruit leather dapat dilihat pada Gambar 3.

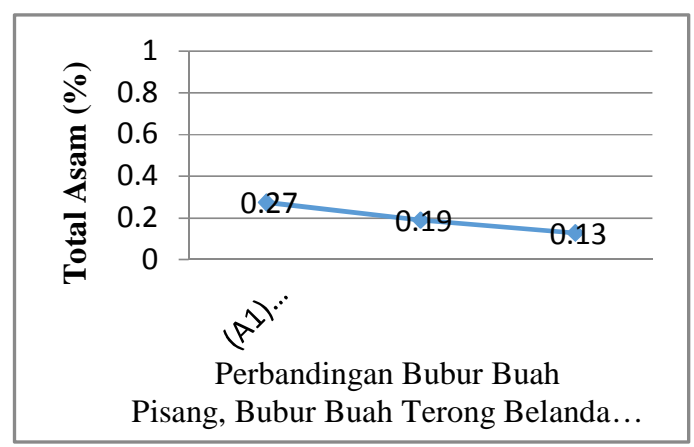

Gambar 3 Pengaruh Perbandingan Pisang Kepok, Terung Belanda dan Gula Terhadap Total Asam fruit Leather

Hasil analisa sidik ragam menunjukkan bahwa adanya pengaruh nyata $(\mathrm{p}<0,05)$ penambahan konsentrasi gula yang berbeda terhadap kadar total asam fruit leather yang dihasilkan sehingga dilakukan uji lanjut Duncan. Hasil uji analisa Duncan memperlihatkan bahwa kadar total asam yang dihasilkan berbeda nyata pada taraf 5\%. Hal ini dikarenakan adanya pengaruh interaksi dari komponen asam dari bubur buah pisang dan bubur buah terung belanda serta jumlah konsentrasi gula yang diberikan. Komponen asam tersebut disebabkan dari buah terung belanda serta asam sitrat yang diberikan. Tingginya kandungan asam serta adanya proses pengolahan yang menyebabkan terjadinya reaksi hidrolisis oleh asam terhadap sukrosa sehingga membentuk fruktosa dan glukosa sehingga semakin banyak gula yang ditambahkan menyebabkan kadar total asam semakin rendah. Hal ini sesuai dengan pernyataan (Bangun, 2009), yang menyatakan bahwa 
asam yang tinggi dan adanya proses pemanasan serta penyerapan air menyebabkan terjadinya reaksi hidrolisis oleh asam terhadap sukrosa membentuk fruktosa dan glukosa. Reaksi tersebut menyebabkan terjadinya penurunan kandungan total asam pada bahan karena sebagian asam digunakan untuk menghidrolisa sukrosa. Hal ini juga didukung pernyataan (Kumalaningsih, Sri, \& Suprayogi, 2006) yang menyatakan bahwa buah terung belanda memiliki kadar keasaman yang tertitrasi sebanyak 1,0-2,6 $(\mathrm{g} / 100 \mathrm{~g})$.

\subsection{2 $\mathrm{pH}$}

$\mathrm{pH}$ (potential of Hydrogen) adalah derajat keasaman yang digunakan untuk menyatakan tingkat keasaman atau basa yang dimiliki oleh satu zat, larutan atau benda. $\mathrm{pH}$ normal memiliki nilai 7 sementara bila nilai $\mathrm{pH}>7$ menunjukkan zat tersebut memiliki sifat basa sedangkan nilai $\mathrm{pH}<7$ menunjukkan keasaman (Nordstrom, Alpers, Ptacek, \& Blowes, 2000). Penentuan $\mathrm{pH}$ dilakukan untuk mengetahui tingkat keasaman pada produk fruit leather pisang kepok dan terung belanda. $\mathrm{pH}$ yang dihasilkan dari penelitian ini yaitu tergolong asam. $\mathrm{pH}$ produk fruit leather dari perlakuan A1 hingga A3 yaitu 5.5. $\mathrm{pH}$ pada produk fruit leather dapat dilihat pada Gambar 4.

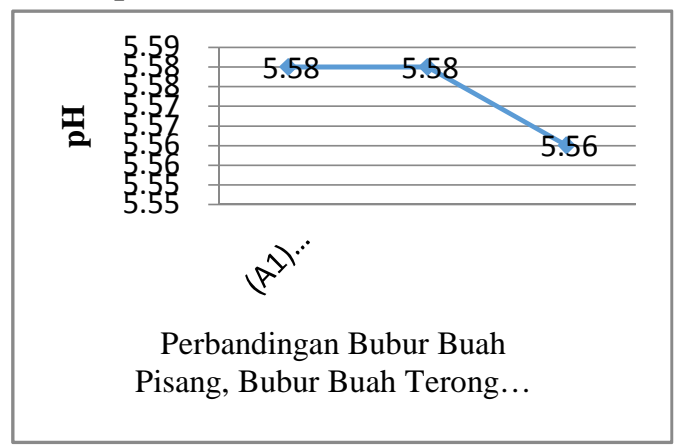

Gambar 4 . Pengaruh Perbandingan Pisang Kepok, Terung Belanda dan Gula Terhadap $\mathrm{pH}$ Fruit Leather

Hasil analisa sidik ragam menunjukkan bahwa tidak adanya pengaruh nyata dari penambahan konsentrasi gula yang berbeda terhadap $\mathrm{pH}$ fruit leather yang dihasilkan sehingga tidak dilakukan uji lanjut Duncan. Hal ini dikarenakan penambahan konsentrasi gula tidak berpengaruh terhadap $\mathrm{pH}$ dari fruit leather. $\mathrm{pH}$ dari fruit leather tersebut tergolong asam disebabkan tingginya kadar asam askorbat yang dimiliki oleh buah terung belanda tersebut. Selain itu asam yang dihasilkan produk berasal dari asam sitrat yang ditambahkan pada pembuatan fruit leather. Hal ini sesuai dengan pernyataan (Hadiwijawa, 2013) yang menyatakan bahwa gula merupakan bahan pangan yang tidak akan mempengaruhi tingkat keasaman suatu produk apabila diberi dengan konsentrasi yang sama maupun berbeda. Hal ini didukung pula oleh pernyataan (Kumalaningsih et al., 2006), yang menyatakan bahwa dalam $100 \mathrm{~g}$ terung belanda mengandung vitamin $\mathrm{C}$ sebesar 11$42 \mathrm{~g}$.

\subsubsection{Antosianin}

Menurut (Winarno, 2002) antosianin dan antoxantin tergolong pigmen yang disebut flavonoid yang pada umumnya larut dalam air. Warna merah keunguan yang teradapat pada buah murbei dihasilkan oleh pigmen warna yang disebut sebagai antosianin. Antosianin tergolong sebagai senyawa flavanoid yang mampu melindungi sel dari ultraviolet dan memiliki banyak manfaat. Kadar antosianin produk fruit leather tertinggi diperoleh pada perlakuan A1 : bubur buah pisang $50 \%$ : bubur buah terung belanda $45 \%$ : gula $5 \%$ yaitu sebesar $212.63 \mathrm{mg} / \mathrm{g}$. Kadar antosianin terendah diperoleh pada perlakuan A3 : bubur buah pisang 40\%: bubur buah terung belanda $35 \%$ : gula $25 \%$ yaitu sebesar $170.16 \mathrm{mg} / \mathrm{g}$. Kadar antosianin pada produk fruit leather dapat dilihat pada Gambar 5 


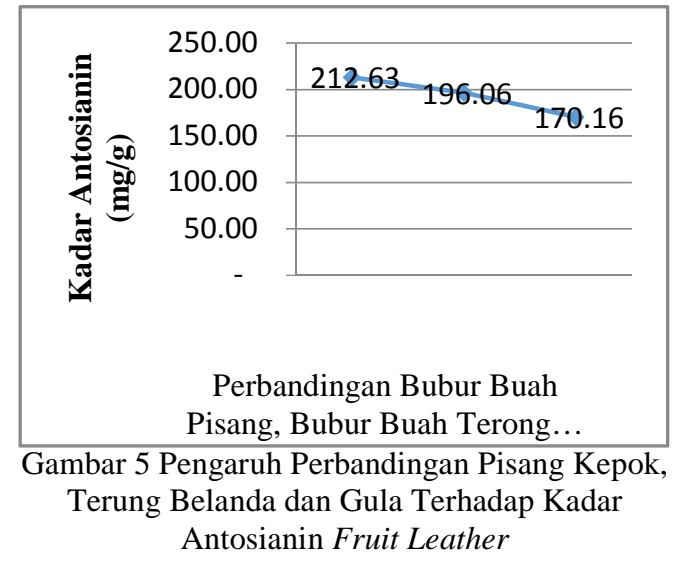

Hasil analisa sidik ragam menunjukkan bahwa adanya pengaruh nyata $(\mathrm{p}<0,05)$ penambahan konsentrasi gula yang berbeda terhadap kadar antosianin fruit leather yang dihasilkan sehingga dilakukan uji lanjut Duncan. Hasil uji analisa Duncan memperlihatkan bahwa kadar antosianin yang dihasilkan berbeda nyata pada taraf $5 \%$. Hal ini membuktikan bahwa semakin tinggi penambahan terung belanda dan semakin sedikit penambahan gula akan menghasilkan kadar antosianin yang tinggi. Hal ini dikarenakan konsentrasi buah terung belanda pada perlakuan A1 lebih tinggi dibandingkan perlakuan yang lainnya, dan pengaruh penambahan gula mampu mempertahankan kadar antosianin pada produk fruit leather. Gula ini mampu mencegah terjadinya degradasi antosianin yang dapat menurunkan stabilitas dari antosianin yang terdapat pada buah terung belanda tersebut. Semakin rendah gula yang digunakan maka semakin menurun jumlah air bebas yang terdapat pada produk tersebut sehingga kadar antosianin dapat terlindungi. Hal ini sesuai dengan pernyataan (Wrolstad, 1990) yang menyatakan bahwa sukrosa dapat membantu mencegah degradasi antosianin dan reaksi pencoklatan pada buah (Nikkah, Khayamy, Heidari, \& Jamee, 2007), menambahkan gula sukrosa hingga konsentrasi 20\% dapat memberikan dampak perlindungan terhadap antosianin. Dampak perlindungan ini diperkirakan berkaitan dengan menurunnya jumlah air bebas.

\subsubsection{Kadar Serat}

Serat yang terkandung dalam bahan makanan merupakan senyawa struktural yang berasal dari dinding sel tanaman seperti selulosa, hemiselulosa pektin, lignin, gum, dan mucilage. Serat tersebut tahan terhadap proses hidrolisis oleh enzim dalam lambung dan usus kecil. Salah satu faktor yang menentukan mutu dan nilai gizi fruit leather adalah kandungan serat kasar yang terdapat dalam bahan (Winarno, 1992). Kadar serat produk fruit leather tertinggi diperoleh pada perlakuan A1 : bubur buah pisang 50\% : bubur buah terung belanda $45 \%$ : gula $5 \%$ yaitu sebesar $1.40 \%$. Kadar serat terendah diperoleh pada perlakuan A3 : bubur buah pisang $40 \%$ : bubur buah terung belanda $35 \%$ : gula $25 \%$ yaitu sebesar $0.61 \%$. Kadar serat pada produk fruit leather dapat dilihat pada Gambar 6.

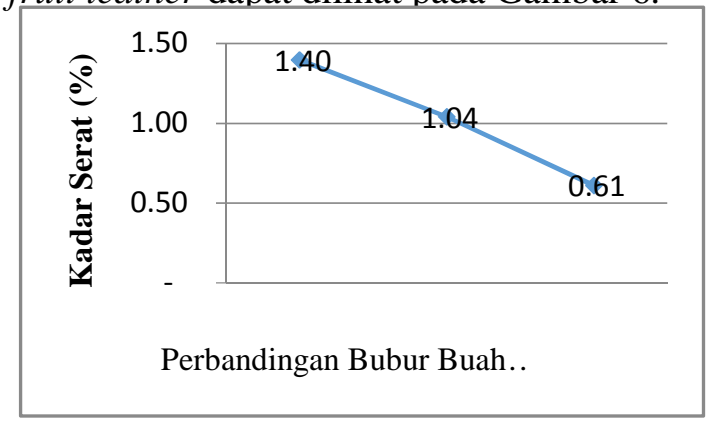

Gambar 6 Pengaruh Perbandingan Pisang Kepok, Terung Belanda dan Gula Terhadap Kadar Serat Fruit Leather

Hasil analisa sidik ragam menunjukkan bahwa adanya pengaruh nyata $(\mathrm{p}<0,05)$ penambahan konsentrasi gula yang berbeda terhadap kadar serat fruit leather yang dihasilkan sehingga dilakukan uji lanjut Duncan. Hasil uji analisa Duncan memperlihatkan bahwa kadar serat yang dihasilkan berbeda nyata pada taraf $5 \%$.Rendahnya kadar serat yang diperoleh pada produk fruit leather juga disebabkan oleh pengaruh proses pengolahan dan lama pengeringan yang dilakukan. Oleh karena itu kadar serat masing-masing buah dalam keadaan segar yang tergolong tinggi mengalami penurunan ketika dilakukan pengolahan. Hal ini sesuai dengan pernyataan (Suprapto, 2004), yang menyatakan bahwa penurunan nilai serat 
kasar disebabkan oleh dinding sel dari bahan terurai selama proses pengolahan dan lama pengeringan juga menyebabkan turunnya kadar serat kasar pada bahan. Hal ini didukung pula oleh pernyataan (Kumalaningsih et al., 2006). yang menyatakan bahwa kandungan serat buah terung belanda yaitu sebanyak 1-4-4.7 $\mathrm{g} / 100 \mathrm{~g}$.

\subsection{Uji Organoleptik \\ 3.4.1. Warna}

Warna merupakan salah satu aspek penting yang dapat digunakan sebagai ukuran dalam menentukan mutu suatu bahan atau produk. Warna juga mempengaruhi tingkat penerimaan konsumen terhadap suatu produk bahan pangan. Bila suatu produk memiliki nilai gizi yang baik, enak dan aroma yang sangat baik, akan tetapi bila warna yang dihasilkan tidak sedap dipandang maka konsumen akan menganggap bahwa produk tersebut telah meyimpang (Winarno, 2004) Warna produk fruit leather tertinggi diperoleh pada perlakuan A3 : bubur buah pisang 40\%: bubur buah terung belanda $35 \%$ : gula $25 \%$ dan A2: bubur buah pisang $45 \%$ : bubur buah terung belanda $40 \%$ : gula $15 \%$ sebesar 3.82. Warna terendah diperoleh pada perlakuan A1 : bubur buah pisang $50 \%$ : bubur buah terung belanda $45 \%$ : gula 5\% yaitu sebesar 3.73. Warna pada produk fruit leather dapat dilihat pada Gambar 7.

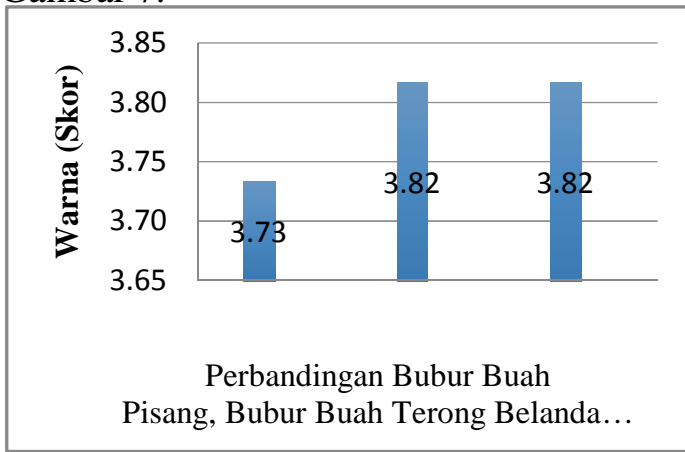

Gambar 7 Pengaruh Perbandingan Pisang Kepok, Terung Belanda dan Gula Terhadap Warna Fruit Leather
Hasil pada gambar diatas menunjukkan adanya perbedaan penilaian terhadap warna pada ketiga perlakuan tersebut dikarenakan pengaruh dari penambahan gula yang diberikan serta pengaruh dari bubur buah yang digunakan, dimana semakin tinggi penambahan konsentrasi gula warna fruit leather semakin disukai oleh panelis dibandingkan dengan penambahan konsentrasi gula dalam jumlah yang rendah. Warna yang diperoleh pun secara visual memiliki warna yang hampir sama yaitu warna merah cerah. Hal ini disebabkan oleh pigmen antosianin yang terdapat pada buah terung belanda menyebabkan warna produk menjadi berwarna merah. Hal tersebut juga dikarenakan terjadinya hidrolisis sukrosa menjadi sukrosa invert sehingga menghasilkan glukosa dan fruktosa. Perubahan warna pada produk yang tidak berbeda jauh dikarenakan adanya polimerisasi yang disebabkan oleh degradasi sukrosa pada saat pemanasan sehingga diduga perubahan warna yang terjadi dikarenakan kontribusi dari warna sukrosa yang ditambahkan. Hal ini sesuai dengan pernyataan (Chafied, Hermana, \& Syarief, 1991), yang menyatakan bahwa hidrolisis sukrosa dengan cara pemanasan menggunakan katalis asam dapat mengakibatkan terjadinya perubahan warna larutan akibat terbentuknya hidroksimetil furfural akibat dehidrasi fruktosa. bahwa fruit leather yang baik memiliki warna khas dari bahan baku jenis buah yang digunakan.

\subsubsection{Aroma}

Aroma yang disebarkan oleh makanan merupakan daya tarik yang sangat kuat dan mampu merangsang indera penciuman sehingga membangkitkan selera. Timbulnya aroma makanan disebabkan oleh adanya senyawa mudah menguap (volatile) dalam makanan maupun reaksi dari suatu proses pekerjaan enzim atau mikroorganisme (Winarno, 2004). Aroma produk fruit leather tertinggi diperoleh pada perlakuan A1 : bubur buah pisang 50\% : bubur buah terung belanda $45 \%$ : gula $5 \%$ 
dan A2 : bubur buah pisang $45 \%$; bubur buah terung belanda $40 \%$ : gula $15 \%$ yaitu sebesar 3.07. Aroma fruit leather terendah diperoleh pada perlakuan A3 : bubur buah pisang $40 \%$ : bubur buah terung belanda $35 \%$ : gula $25 \%$ yaitu sebesar 2.87. Aroma pada produk fruit leather dapat dilihat pada Gambar 8.

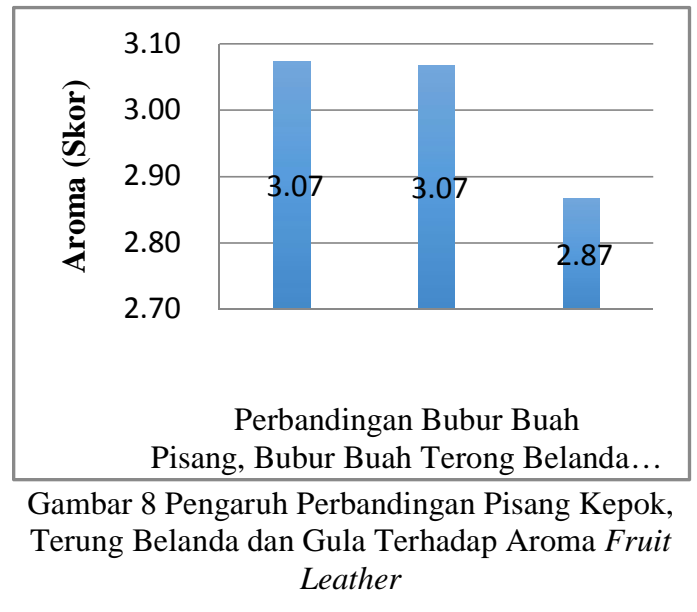

Hasil pada gambar diatas menunjukkan adanya perbedaan penilaian terhadap aroma pada ketiga perlakuan tersebut dikarenakan pengaruh dari penambahan gula yang diberikan serta pengaruh dari bubur buah yang digunakan, dimana semakin rendah penambahan gula yang digunakan semakin disukai aroma dari fruit leather tersebut, begitu juga dengan konsentrasi buah yang digunakan yaitu lebih disukai bubur buah pada konsentrasi yang tinggi. Hal ini dikarenakan aroma dominan yang muncul yaitu berasal dari aroma khas dari bubur buah pisang, karena buah pisang tersebut mempunyai kandungan senyawa volatile yang dapat memunculkan aroma khas dari buah tersebut sehingga semakin banyak penambahan gula maka aroma kurang disukai karena penambahan gula dalam konsentrasi tinggi menyebabkan gula mengalami karamelisasi pada saat pemanasan sehingga aroma caramel akan muncul. Hal ini sesuai dengan pernyataan (Winarno, 2004) yang menyatakan bahwa gula akan mengalami karamelisasi apabila terkena panas tinggi. Gula karamel akan menimbulkan aroma karamel. Aroma cara meloleh gula tidak memerlukan interaksi dari asam sitrat. Hal ini didukung pula oleh pernyataan (Pino \& Febles, 2013), yang menyatakan bahwa aroma khas pisang ditimbulkan dari komponen-komponen volatile.

\subsubsection{Rasa}

Rasa merupakan faktor yang paling penting dalam pengujian organoleptik yang juga merupakan faktor penentuan daya terima konsumen. Rasa dipengaruhi oleh beberapa faktor, yaitu senyawa kimia, suhu, konsentrasi dan interaksi dengan komponen rasa yang lain (Winarno, 2004). Rasa produk fruit leather tertinggi diperoleh pada perlakuan A3 : bubur buah pisang $40 \%$ : bubur buah terung belanda $35 \%$ : gula $25 \%$ yaitu sebesar 3.30. Rasa produk fruit leather terendah diperoleh pada perlakuan A2 : bubur buah pisang $45 \%$; bubur buah terung belanda $40 \%$ : gula $15 \%$ yaitu sebesar 3.13. Rasa pada produk fruit leather dapat dilihat pada gambar 9.

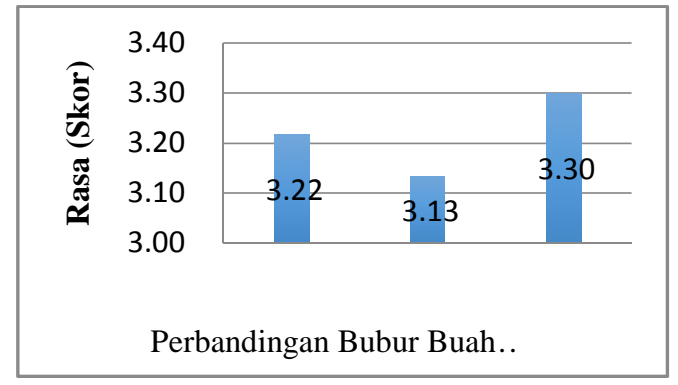

Gambar 9 Pengaruh Perbandingan Pisang Kepok, Terung Belanda dan Gula Terhadap Aroma Fruit Leather

Hasil pada gambar diatas menunjukkan bahwa adanya perbedaan penilaian terhadap rasa pada ketiga perlakuan tersebut dikarenakan pengaruh dari penambahan gula dan rasa asam dari bubur buah terung belanda, dimana semakin tinggi penambahan gula rasa fruit leather semakin disukai oleh panelis, namun pada perlakuan A2 nilai kesukaan terhadap rasa menurun yaitu lebih rendah dari perlakuan A1 yang menggunakan gula hanya dengan konstentrasi 5\%. Rasa manisfruit leather berasal dari gula yang bersifat murni sebab gula tidak meninggalkan after teste pada makanan. Namun tingginya konsentrasi gula tidak 
membuat rasa manis yang berlebihan pada fruit leather campuran pisang kepok dan terung belanda yang dihasilkan. Sedangkan rasa asam yang timbul pada fruit leather campuran pisang kepok dan terung belanda memberikan efek asam yang menyegarkan dan menyeimbangkan rasa manis yang dihasilkan oleh pisang kepok dan terung belanda itu sendiri dan dari penambahan gula yang membentuk keseimbangan yang lebih baik dengan keasaman, sehingga citarasa menjadi lebih menonjol. Hal ini sesuai dengan pernyataan (Winarno, 1997), yang menyatakan bahwa rasa dipengaruhi oleh beberapa faktor seperti senyawa kimia, suhu, dan interaksi dengan komponen rasa yang lainnya. Berbagai senyawa kimia menumbuhkan rasa yang berbeda. Rasa manis ditimbulkan oleh senyawa organik aliafatik yang mengandung gugus $\mathrm{OH}$ seperti alkohol, beberapa asam amino dan gliserol. Rasa asam disebabkan oleh ion $\mathrm{H}_{+}$. Sumber rasa manis yang utama adalah sukrosa, sumber rasa asam adalah asam sitrat, sedangkan kandungan serat menimbulkan (Mouth Feel) rasa berisi.

\subsubsection{Tekstur}

Tekstur merupakan sensasi tekanan yang dapat diamati dengan mulut (pada waktu digigit, dikunyah, ditelan) ataupun dengan perabaan dengan jari manis. Penilaian biasanya dilakukan dengan menggosokkan jari dari bahan yang dinilai diantara kedua jari (Winarno, 2004). Tekstur produk fruit leather tertinggi diperoleh pada perlakuan A1 : bubur buah pisang $50 \%$ : bubur buah terung belanda $45 \%$ : gula $5 \%$ dan A2 : bubur buah pisang $45 \%$; bubur buah terung belanda $40 \%$ : gula $15 \%$ yaitu sebesar 3.25. Tekstur produk fruit leather terendah diperoleh pada perlakuan A3 : bubur buah pisang $40 \%$ : bubur buah terung belanda $35 \%$ : gula $25 \%$ yaitu sebesar 2.53 . Tekstur pada produk fruit leather dapat dilihat pada gambar 10

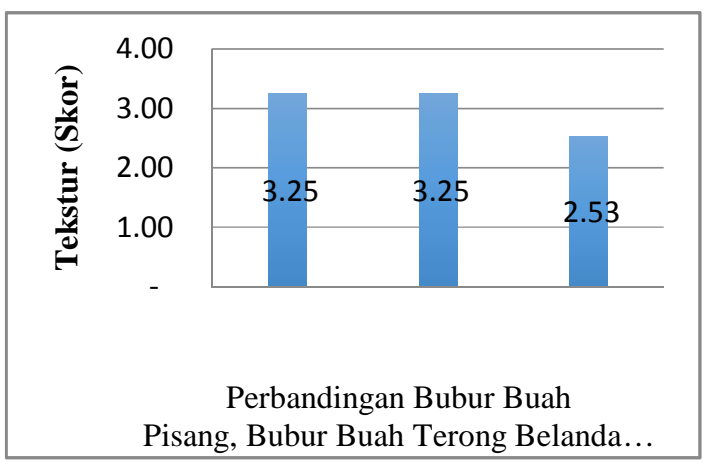

Gambar 10 Pengaruh Perbandingan Pisang Kepok, Terung Belanda dan Gula Terhadap Aroma Fruit Leather

Hasil pada gambar diatas menunjukkan bahwa adanya perbedaan penilaian terhadap tekstur pada ketiga perlakuan tersebut dikarenakan pengaruh dari penambahan gula, dimana semakin tinggi penambahan gula maka tekstur fruit leather semakin kokoh dan agak mengeras sehingga kurang disukai oleh panelis. Hal ini dikarenakan peningkatan konsentrasi gula yang digunakan menyebabkan air diikat oleh gula sehingga menghasilkan gel yang lebih kokoh dan berakibat gel menjadi keras. Hal ini sesuai dengan pernyataan (Muchtadi, 1989), yang menyatakan bahwa gula disamping berfungsi sebagai pemberi tekstur juga berfungsi untuk mengawetkan, pemberi penampakan, dan flavor yang ideal.

\section{KESIMPULAN}

Kesimpulan yang diperoleh dari penelitian ini adalah sebagai berikut

1. Fruit Leather dengan perbandingan bubur buah dan konsentrasi gula yang terbaik yaitu pada perlakuan A1 dengan perbandingan $50 \%$ pisang : $45 \%$ terung belanda : $5 \%$ gula menghasilkan kadar air $10,95 \%$, total asam $0,27 \%, \mathrm{pH} 5.5$, antosianin $212,63 \mathrm{mg} / \mathrm{g}$, serat $1,04 \%$, serta agak disukai oleh panelis berdasarkan uji organoleptic parameter aroma, rasa dan tekstur.

2. Penambahan konsentrasi gula yang tinggi serta puree buah yang rendah berpengaruh dalam penurunan kadar air, total asam, kadar antosianin dan kadar 
serat. Namun tidak berpengaruh terhadap $\mathrm{pH}$.

\section{DAFTAR PUSTAKA}

AOAC. (1990). Official Methods of Analysis of AOAC International. In Association of Official Analysis Chemists International. https://doi.org/10.3109/155636576089 88149

Badan Pusat Statisti. (2013). Sumatera Barata Dalam Angka. Padang: BPS Press.

Bangun. (2009). Pengaruh Konsentrasi Gula Dan Campuran Sari Buah (Markisa, Wortel dan Jeruk)Terhadap Mutu Serbuk Minuman Penyegar. USU.

Buckle, \& Edward. (1987). Ilmu Pangan. Terjemahan Purnomo dan Adiono. Jakarta: Universitas Indonesia Press.

Chafied, Hermana, \& Syarief. (1991). Mempelajari proses pembuatan sirup gula invert dari nira (Arrenga pinata Merr). Buletin Pusbangtepa. Bogor: Institut Pertanian Bogor.

Giusti, M. M., \& Wrolstad, R. E. (2001). Characterization and measurement of anthocyanins by UV- Visible spectroscopy. In Current Protocols in Food Analytical Chemistry. https://doi.org/10.1002/0471142913.fa f0102s00

Hadiwijawa. (2013). Pengaruh Perbedaan Penambahan Gula Terhadap Karakteristik Sirup Buah Naga Merah. Padang: Universitas andalas.

Kumalaningsih, Sri, \& Suprayogi. (2006). Tamarillo (Terung Belanda) TanamanBerkhasiat Penyedia Antioksidan Alami. Surabaya: Trubus Agrisarana.

Muchtadi. (1989). Evaluasi Nilai Gizi Pangan. Pangan dan Gizi, Institut Pertanian Bogor.

Musfiroh, Indriyati, \& Muchtaridi. (2009). Analisis Proksimat danPenetapan Kadar $\quad \beta$-Karoten dalamSelai Lembaran Terung Belandadengan
Metode Spektrometri SinarTampak. Jurnal Penelitian FakultasFarmasi Universitas Padjadjaran. Bandung.

Nikkah, Khayamy, Heidari, \& Jamee. (2007). Effect of Sugar Treatment on Stability of Anthocyanin Pigments in Berries,. Journal of Biological Sciences, 8(7), 1412-1417.

Nordstrom, D. K., Alpers, C. N., Ptacek, C. J., \& Blowes, D. W. (2000). Negative $\mathrm{pH}$ and Extremely Acidic Mine Waters from Iron Mountain, California.

Pino, J. A., \& Febles, Y. (2013). Odouractive compounds in banana fruit cv. Giant Cavendish. Food Chemistry. https://doi.org/10.1016/j.foodchem.20 13.03.064

Rampengan. (1985). Dasar - Dasar Pengawetan Mutu Pangan. Makassar: Badan Kerjasama Perguruan Tinggi Negeri Indonesia Bagian Timur, Makassar.

Rohimah. (2016). Outlook Komoditas Pertanian Sub Sektor Hortikultura (Pisang). Pusat Data Dan Sistem Informasi Pertanian.

Sudarmadji, Haryono, S. B., \& Suhardi. (1997). Prosedur Analisis Bahan Makanan dan Pertanian. Yogyakarta: Liberty.

Suprapto. (2004). Pengaruh Lama Blancing Terhadap Kualitas Stik ubi Jalar Ipoema batatas L .) dari Tiga Varietas. Prosiding.

Winarno. (1992). Kimia Pangan dan Gizi. Jakarta: gramedia Pustaka Utama.

Winarno. (1997). kimia pangan dan Gizi. Jakarta: PT Gramedia Pustaka Utama.

Winarno. (2002). Kimia Pangan dan Gizi. Jakarta: PT. Gramedia Pustaka Utama.

Winarno. (2004). Kimia Pangan dan Gizi. Jakarta: gramedia Pustaka Utama.

Wrolstad. (1990). . (Influence of sugar on anthocyanin pigmen stability in frozen strowberries. . . Food Sci, 55, 10641065. 